\title{
Economic prospects for using the excursion potential of urban environments (case of Rostov-on-Don)
}

\author{
Tatiana Zainullina ${ }^{1 *}$, Irina Kedrova ${ }^{1}$, Liliya Karich $^{1}$, and Ruslan Tikidzhyyan ${ }^{1}$ \\ ${ }^{1}$ Don State Technical University, Gagarina Sq., 1, Rostov-on-Don, 344000, Russia
}

\begin{abstract}
The article studies the issue of analyzing the possibilities of using urban objects for excursions from the point of view of economic benefits, since the tourism component is present in the economy of any city. Tourism and excursion services bring income to the city budget, the article considers the features of using excursion services at the facilities of the urban environment of Rostov-on-Don.
\end{abstract}

\section{Introduction}

The most important indicators that characterize the possibility of using urban objects for touristic excursion services, in addition to the quality of excursions and the number of tourists using the services of excursion bureaus and tourist organizations, is the economic effect that the city economy receives from the tourist flow.

\section{Materials and methods}

The concept and the meaning of economic indicators of the tourism industry was investigated. By Tohidy F. (2011) [1]. The effects of the impact of the tourism industry on the economy were investigated by Mayer M. and Vogt L. (2016) [2].

The urban environment as a concept and its impact on human well-being and economic development was studied by Anne Caroline Krefis and other (2018) [3], Bai X. and other (2017) [4]. Shushu Li, Yong Ma [5] (2014). Urban management was investigated by Cosmina L. Voinea and other [6] (2020). Barke, M. [7]

Charles R. (2011) [8] considered the theoretical foundations of tourism activities, highlighted the concept of tourism management and considered the connection of tourism with other areas of activity, including the urban environment, as well as tourism as a factor in the development of the economy.

Pantano E, Priporas C., Stylos N. (2017) [9] investigated the reaction of tourists to various attractions, which allows you to develop the most interesting and popular tours and excursions, as well as the impact of social networks on the decision-making processes about visiting sights.

\footnotetext{
* Corresponding author: tat-zajnullina@yandex.ru
} 
Buhalis D., Amaranggana A. (2015) [10] analyzed the process of personalization of tourist and excursion services as influencing their choice, as a result of which the income of tourist organizations providing such services increases.

Ahani, A. (2019) [11] and other considered the segmentation and forecasting of the development of the tourism market through online reviews on OTA sites.

The impact of the pandemic on the tourism and excursion services market was studied by Asad A. Aburumman (2020) [12], Brouder P. (2020) [13].

The role of guides in the journey was considered by Liljeblad J. (2020) [14], since the quality of excursion services depends on his responsible attitude. Budnikevych I, Gavrysh I. (2017) [15] justify modern marketing concepts as the basis for forming and increasing the attractiveness of cities and territories. Rakhmanov, A. (2019) highlighted the attractiveness structure of megacities for tourists [16].

Also, the problems of tourism and the hospitality industry development and their impact on economic development were addressed Kazmina, L. and other [17, 18], Provotorina, V.V. and other [19], Zainullina T., Kedrova I. [20], Ekinil, G. and other [21].

The following research methods were used in the work: analysis of scientific sources, synthesis of scientific ideas, foreign experience, description of the concept. Statistical observation and analysis methods.

\section{Results}

The definition of "urban habitat (residence)" was developed and put into scientific terminology by the All-Russian Public Organization "Russian Union of Engineers," the Ministry of Regional Development of the Russian Federation and the Federal Agency for Construction and Housing and Communal Services of the Russian Federation during the implementation of subparagraph d) Item 1 of Instructions of the President of the Russian Federation No. Pr-534 dated February 29, 2012, issued following the meeting "On Measures to Implement the Housing Policy" dated February 14, 2012 [22].

In the future, according to paragraph 4 of the list of instructions of the Chairman of the Government of the Russian Federation dated March 20, 2012 No. VP-P9-1581 "On the development of a methodology for assessing the quality of the urban environment and conducting such an assessment in large cities of Russia" by the Ministry of Regional Development of the Russian Federation. A methodology and basis for assessing the quality of urban living environment (habitat) were created by the Russian Union of Engineers when forming the General Rating of Attractiveness of Russian Cities.

An urban environment is a set of many objects that form space, and the relationship within that space. The city is a complex, constantly changing organism, which is influenced by the political and socio-economic situation. In addition, the attractiveness of the city for tourists, the volume of tourist flow passing through a particular city annually, directly affects the appearance of the urban environment and its development opportunities.

\section{Discussion}

In October 2020, the consulting company "Resonance Consultancy," specializing in work in the field of real estate and economic development, unveiled a new edition of the ranking of the best cities in the world for living, business and tourism "The World's 100 Best Cities." Moscow in it is located in fourth place against the fifth line a year earlier. St. Petersburg also got into the rating in 2020, located in 16th place (in the previous list, the Russian city was in 35 th place). 
Similar ratings are also held in Russia, for example, there is a "Rating of the event potential of the regions," which is compiled on the basis of the activity of Russian cities. Among the factors influencing the place in the ranking, indicators affecting the development of business and event tourism were taken into account: infrastructure, policies for the development of congress and exhibition potential, a program for promoting the region, its experience in conducting high-level events, tourist attractiveness and transport accessibility.

According to the results of 2019, St. Petersburg has been the first in terms of the development of the event industry for the fourth year in a row. The second position (and it is unchanged for the sixth year in a row) is in Yekaterinburg. The third place belongs to Kazan. The top ten potentially attractive cities also included Sochi, Krasnodar, Ufa, Nizhny Novgorod, Samara, Rostov-on-Don and Krasnoyarsk.

According to the National Tourist Rating 2020, the Rostov Region again entered the "Golden Twenty" and the TOP-5 of regions that maximally retained the number of tourists in 2020. The study was conducted by the journal on domestic and inbound tourism "Rest in Russia" together with the center of information communications "Rating." The criteria for evaluation were: the level of development of the tourism industry and hotel infrastructure of the region, the popularity of the region among tourists who come for several days, the tourist uniqueness and attractiveness of the region, etc.

Rostov-on-Don is the administrative center of the Rostov region, one of the largest cities in the South of Russia, a key transport center. Located in the southeast of the East European Plain, mainly on the right bank of the estuary part of the river. Don, $46 \mathrm{~km}$ from its confluence with the Taganrog Bay of the Sea of Azov. The city has a successful location in relation to the transport hubs of Russia (railway and bus stations, airport, M-4 route "Don"). Neighbouring territories with a high population density are potentially able to provide additional entry tourist flow. According to official sources, despite the pandemic, the volume of tourist flow in 2020 increased by 30\% compared to 2019 and amounted to about 1.5 million people. The most visited attractions among tourists in the Rostov region were the Azov Historical, Archaeological and Paleontological Museum-Reserve (57.1 thousand), the Tanais Archaeological Museum-Reserve (33.3 thousand) and the Rostov Regional Museum of Local History (12.5 thousand).

If we compare this indicator since 2015 , then there is an increase in tourist flow by almost $70 \%$. This is explained, first of all, by the large number of transit guests coming to the region on their way to the resorts of the Krasnodar Territory and holding the World Cup in 2018. As can be seen from Fig. 1, in 2020, Rostov Region reached 9th place in terms of growth in tourist flow compared to 2019 . 


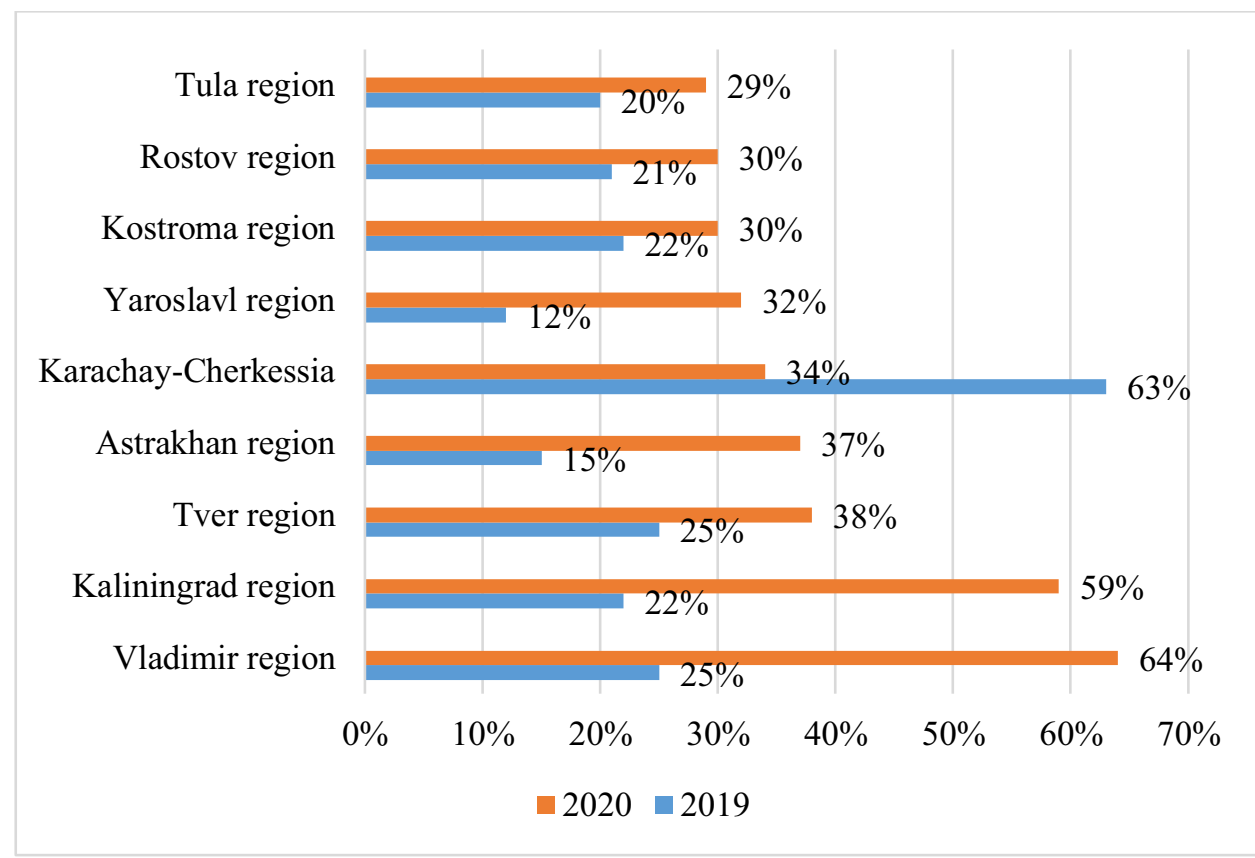

Fig. 1. Top 10 regions of the Russian Federation in terms of tourist flow growth in 2020.

Excursion activity in Rostov-on-Don has a long tradition. In the Soviet years, the city a large business center of the south of the RSFSR, located on the path of a planned tourist flow (until the end of the $80 \mathrm{~s}$ of the twentieth century), hosted travel tourists, as well as organized tourist groups. The excursion bureaus of those years, in general, did not have problems with the objects of the tourist show. The most popular for the target categories of tourists remained excursions on revolutionary-patriotic, military topics. Traditionally, we could observe sightseeing tours of the city, art history tours, industrial enterprises of Rostov-on-Don, etc.

To maintain interest in cultural and cognitive tourism, both guests from different cities and local residents need to constantly expand the line of excursion programs, saturate them with exclusive, popular topics for wide target groups, supplement traditional, sometimes outdated routes with new objects of display.

According to «RussianFirms», 175 companies are registered in Rostov-on-Don, in the activities of which there is excursion service. Including 138 enterprises are engaged in travel agent activities, 32 - tour operator and travel agent activities and 5 - tour operator activities. 
Table 1. Financial indicators of activities of tour companies of Rostov-on-Don in 2019.

\begin{tabular}{|c|c|c|c|c|c|c|c|c|}
\hline & \multirow{2}{*}{\multicolumn{2}{|c|}{$\begin{array}{l}\text { All travel } \\
\text { agencies }\end{array}$}} & \multicolumn{6}{|c|}{ including travel agencies engaged in: } \\
\hline & & & \multicolumn{2}{|c|}{$\begin{array}{l}\text { Tour operator } \\
\text { activities }\end{array}$} & \multicolumn{2}{|c|}{$\begin{array}{c}\text { Tour operator } \\
\text { and travel } \\
\text { agency activities }\end{array}$} & \multicolumn{2}{|c|}{$\begin{array}{l}\text { Travel agency } \\
\text { activities }\end{array}$} \\
\hline & total & $\begin{array}{l}\% \text { to } \\
\text { total }\end{array}$ & total & $\begin{array}{l}\% \text { to } \\
\text { total }\end{array}$ & total & $\begin{array}{l}\% \text { to } \\
\text { total }\end{array}$ & total & $\begin{array}{l}\% \text { to } \\
\text { total }\end{array}$ \\
\hline & \multicolumn{8}{|c|}{ Funds received from the sale of tourist product thousand rubles } \\
\hline total & 5148057 & 100 & 3970442 & 77,1 & 785005 & 15,2 & 392610 & 7,6 \\
\hline \multirow[t]{2}{*}{$\begin{array}{l}\text { per travel } \\
\text { company }\end{array}$} & 29417,5 & & 794088,4 & & 24531,4 & & 2845 & \\
\hline & \multicolumn{8}{|c|}{$\begin{array}{c}\text { Including the amount of commissions, agency and other fees, thousand } \\
\text { rubles }\end{array}$} \\
\hline total & 516620 & 100 & 32140 & 6,2 & 91869 & 17,8 & 392610 & 76 \\
\hline $\begin{array}{l}\text { per travel } \\
\text { company }\end{array}$ & 2952,1 & & 6428 & & 2870,9 & & 2845 & \\
\hline
\end{tabular}

Thus, it can be concluded that, despite the difficulties, tourist and excursion activities continue to develop.

International outbound tourism

Implemented tour packages to the population of the whole

3844309.4

4715513.9

795982.1

1186035.7

4655300.1

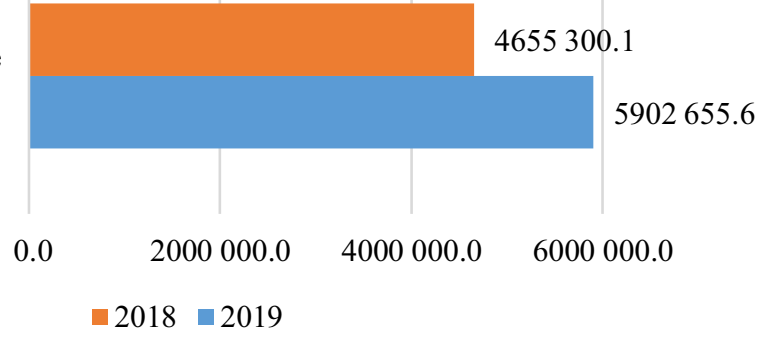

Fig. 2. Cost of tourist packages sold to the population thousand rubles. 
The oldest sightseeing bureau of Rostov-on-Don "Sputnik" in 2021 offers 38 sightseeing programs cost from 700 to 7800 rubles. The most popular among guests of the city is a group team bus and pedestrian tour of the city cost 1200 rubles. per person.

1 The Native Spaces sightseeing bureau offers 150 sightseeing programs in the city and the region costing from 200 rubles. up to 5,000 rubles. per person, but the most popular are a sightseeing tour in Rostov-on-Don worth 980 rubles. and an excursion to Loga Park + USSR Legends Museum worth 1300 rubles. per person, as well as an unusual pedestrian excursion "Secrets and ghosts of Rostov osts" - 750 rubles. and a traditional excursion to Starocherkassk - 1090 rubles..

On March 8, 2021, the third stage of the cashback program began. It will last until June 15, 2021. Now 10 companies from the Rostov Region participate in the action: Reina-Tour NTV, Saga Voyage, EXALAIN, Sudakov Travel, AVIA CITY, Own Company, LT Tour, Golden Compass, In addition, tours in the Rostov region sell 17 foreign and federal tour operators, including Russian Railways Tour, Europort, Vedi Tour Group, WAND and Dolphin, at the Tourist Cashback stock. Cruise tours, including a visit to the region, are among the proposals of Vodokhod and Doninturflot.

The main question is about the effectiveness of the program and what effect it brings for the Rostov region. We can say that the program is effective and is becoming more and more popular among tourists. At the first stage of the cashback campaign from August 21 to 28, 2020, 7 tour operators and 25 collective placement facilities took part in the program from the Rostov Region. 9 tours were sold in the Rostov region for 44 people and 2 reservations were made in hotels. The total amount is more than 800 thousand rubles. Another 6 rounds for 14 people were sold to residents of the region in other regions of the Russian Federation in the amount of more than 380 thousand rubles.

At the second stage of the cashback from October 15 to December 5, 10 tour operators and 58 collective accommodation facilities took part in the program. During his period of operation, 15 tours were sold in the Rostov region for 32 people for a total amount of more than 1 million rubles, as well as 105 tours for 210 people to other regions of the Russian Federation for more than 4.5 million rubles.

The Government of the Russian Federation in the "Strategy for the Development of Tourism in the Russian Federation" and in the "Strategy for the Development of Tourism in the Republic of Moldova" emphasizes the need to develop excursion work, which affects not only the attractiveness of the region, but also the educational process.

If we talk about socio-economic factors that affect the possibilities for developing excursion potential, then they can be divided into two groups - generating and implementing. Among the main factors generating the development of the excursion services market are the development of related industries, the need to restore working capacity and health, and the process of urbanization. Implementing factors that can directly influence this activity - the growth of the material and cultural-educational level, arouse interest in excursions; increased free time leads to the need to change forms of activity including in the tourist and excursion format. The development of transport and communications and the expansion of the service sector also have a positive impact on these areas.

For further research on the economic use of excursion potential, it is proposed to monitor the recognition of urban objects for use in tourist and excursion programs.

\section{Conclusion}

The following conclusions can be drawn from the study:

1. A study of the economic use of the excursion potential of the urban environment in Rostov-on-Don allows us to identify the most promising excursion programs in terms of 
profitability, and it is important to note that these excursions can be interesting not only to tourists, but also to residents of Rostov-on-Don and to the Rostov region.

2. The importance of monitoring the excursion potential is due to the need to consider the main trends in the development of the tourism industry, to identify the needs of companies that work in this industry, as well as to determine the development directions of excursion facilities.

3. The number of companies operating in the field of tourist and excursion services is growing every year, programs are being developed taking into account the requests and preferences of customers, which, of course, affects the expansion of the range of tours offered and contributes to the growth of income from excursion activities in the total income of tourist companies.

\section{References}

1. F. Tohidy, International Journal of Business and Management, 6(8) (2011), DOI:10.5539/ijbm.v6n8p206

2. M. Mayer, and L. Vogt, De Gruyter Oldenbourg, 8(2), 169-198 (2016), DOI 10.1515/tw-2016-0017

3. A.C. Krefis, et al., Urban Science, 2 (2018), DOI:10.3390/urbansci2010021

4. X. Bai, et al., Annual Review of Environment and Resources, 42, 215-240 (2017), DOI: 10.1146/annurev-environ-102016-061128

5. L. Shushu, Y. Ma, Economic Development, 6, 5143-516 (2014), DOI: $10.3390 /$ su6085143

6. C.L. Voinea, et al., Open University of the Netherlands, 12 (2020), DOI: $10.3390 /$ su 12135309

7. M. Barke, Teaching Urban Morphology, 11-30 (2018), DOI: 10.1007 / 978-3-31976126-8_2

8. C.R. Goeldner, J. R. Brent Ritchie, Tourism: Principles, Practices, Philosophies, 12th Edition (John Wiley \& Sons, Inc, Hoboken, 2011)

9. E. Pantano, C. Priporas, N. Stylos, Tourism Management, 60, 430-438 (2017), DOI:10.1016/j.tourman.2016.12.020

10. D. Buhalis, A. Amaranggana, Information and Communication Technologies in Tourism, 553-564 (2013), DOI: 10.1007/978-3-319-03973-2_40.

11. A. Ahani, M. Nilashi, O. Ibrahim, L. Sanzogni, S. Weaven, International Journal of Hospitality Management, 80, 52-77 (2019), DOI: 10.1016 / J.IJHM.2019.01.003

12. A.A. Aburumman, Humanities and Social Sciences Communications 5 (2020)

13. P. Brouder, Tourism Geography, 1-7 (2020), https://doi.org/10.1080/14616688.2020.1760928

14. J. Liljeblad, Tourist Studies, 20(3), 314-335 (2020), https://doi.org/10.1177/1468797620920991

15. I. Budnikevych, I. Gavrysh, Baltic Journal of Economic Studies, 1 (2017)

16. A. Rakhmanov, Balt. Reg., 11(2), 73-93 (2019), DOI: 10.5922/2079-8555-2019-2-5

17. L. Kazmina, V. Provotorina, V. Makarenko, A., Petrenko, E3S Web of Conferences, 210, 12001 (2020), DOI: https://doi.org/10.1051/e3sconf/202021012001

18. L.N. Kazmina, V.S. Makarenko, V.V. Provotorina, T.N. Grigorenko, Journal of Economics and Business Administration, 7, 510-520 (2019), DOI: 10.35808/ijeba/297 
19. V.V. Provotorina, L.N. Kazmina, A.S. Petrenko, V.S. Makarenko, Lecture Notes in Civil Engineering, 130, 20-32 (2020), DOI: https://doi.org/10.1007/978-981-33-62086_3

20. T. Zainullina, I. Kedrova, E3S Web of Conferences, 8, 22024 (2020), DOI https://doi.org/10.1051/e3sconf/202021022024

21. G. Ekinil, V. Provotorina, A. Petrenko, L. Gorgadze, E3S Web of Conferences, 217, 05006 (2020), DOI: https://doi.org/10.1051/e3sconf/202021705006.

22. A.S. Boeva, Federation Russian Science and Education Today: Problems and Prospects, 1(26), 3-5 (2019) 